\title{
Long-Term Monitoring of Radiocesium Concentration in Sediments and River Water along Five Rivers in Minami-Soma City during 2012-2016 Following the Fukushima Dai-ichi Nuclear Power Plant Accident
}

\author{
Kiyoshi Shizuma ${ }^{1, *}$, Wim Ikbal Nursal ${ }^{2}$ and Yushi Sakurai ${ }^{3}$ \\ 1 Graduate School of Engineering, Hiroshima University, Higashi-Hiroshima, Hiroshima 739-8527, Japan \\ 2 Graduate School of Integrated Arts and Sciences, Hiroshima University, Higashi-Hiroshima, \\ Hiroshima 739-8521, Japan; bangwim@gmail.com \\ 3 NPO Corporation Furusato, 2-144-6 Takami-Cho, Minami-Soma, Fukushima 975-0033, Japan; \\ u.4.-nikken@piano.ocn.ne.jp \\ * Correspondence: shizuma@hiroshima-u.ac.jp
}

Received: 7 July 2018; Accepted: 6 August 2018; Published: 7 August 2018

Featured Application: Rapid decrease of radiocesium contamination through the rivers was observed but high accumulation of radiocesium over floodplains in the downstream areas should be noted for future river decontamination.

\begin{abstract}
Radiocesium monitoring in sediments and river water has been conducted along five rivers in Minami-Soma City during 2012-2016 to clarify the temporal changes of radiocesium contamination in these rivers. Sampling has been performed annually under normal flow conditions. Sediment and river water samples were collected from four or five sampling sites along each river. Gamma-ray measurements of sediments were performed using a low-background Ge detector and unfiltered river water was utilized to determine radiocesium concentration using a well-type Ge detector. The ${ }^{137} \mathrm{Cs}$ concentration in sediments was highest at upstream sites and slowly decreased to downstream sites for all rivers reflecting the high radioactive contamination in the upstream area. Temporal decrease of the ${ }^{137} \mathrm{Cs}$ concentration was observed in sediments and river water for each river. The effective half-lives were 1.3-2.1 y for sediments, and 0.9-2.1 y for river water from rivers with upstream dams. On the undammed river, the effective half-lives were $4.7 \mathrm{y}$ and $3.7 \mathrm{y}$ for sediment and river water, respectively. Much longer effective-half-lives might reflect the direct transfer of radiocesium from forests and plains to the river. The ${ }^{137} \mathrm{Cs}$ concentration in riverbed was low in downstream areas, however, accumulation of ${ }^{137} \mathrm{Cs}$ over the floodplain was observed. Rapid decrease of ${ }^{137} \mathrm{Cs}$ contamination through rivers will put residents at ease, but high accumulation of radiocesium over floodplains should be noted for future river decontamination.
\end{abstract}

Keywords: long-term monitoring; radiocesium; FDNPP; Minami-Soma City; sediments; river water; effective half-life

\section{Introduction}

A nuclear reactor accident occurred at Fukushima Dai-ichi Nuclear Power Plant (FDNPP) in Japan on 11 March 2011, causing massive radioactive contamination [1-7] in Fukushima and neighboring prefectures. The short-lived radionuclides rapidly decayed out, but radionuclides ${ }^{137} \mathrm{Cs}$ (half-life $=30.1 \mathrm{y}),{ }^{134} \mathrm{Cs}(2.06 \mathrm{y})$ and ${ }^{90} \mathrm{Sr}(28.9 \mathrm{y})$ retained rather longer times in the environment. The total release of ${ }^{137} \mathrm{Cs}$ and ${ }^{134} \mathrm{Cs}$ from the FDNPP were estimated to be $24 \mathrm{PBq}$, which was lower 
than $132 \mathrm{PBq}$ in the case of the Chernobyl accident [1]. The ratio of ${ }^{90} \mathrm{Sr} /{ }^{137} \mathrm{Cs}$ was estimated lower than about $1 / 1000$ [1,2]; thus ${ }^{137} \mathrm{Cs}$ and ${ }^{134} \mathrm{Cs}$ are the main radionuclides to be traced in the environment.

Radiocesium $\left({ }^{137} \mathrm{Cs}+{ }^{134} \mathrm{Cs}\right.$ ) deposited on the ground quickly binds to fine soil particles, as reported by He and Walling [8] and Tsukada et al. [9]. The transfer process of radiocesium from forest to river environments was reviewed by Evrard et al. [10] and they suggested that soil erosion by rainfall is one of main process of the radiocesium transfer. River surveys in Fukushima were performed by many authors. Ueda et al. [11] measured the transport of radiocesium through two rivers (Hiso and Wariki Rivers) in the Iitate Village. The discharge of radiocesium was estimated to be $0.3 \%$ and $0.5 \%$ of total amount of radiocesium deposition on the catchments of these rivers, respectively. Yoshimura et al. [12] studied the concentrations of particulate/dissolved radiocesium in river water at 30 sites in Fukushima and Miyagi Prefectures in December 2012, and evaluated the solid/liquid distribution coefficients of ${ }^{137}$ Cs. Sakaguchi et al. [13] and Tanaka et al. [14] studied the particle size dependence of radiocesium concentration in river water and riverbed sediments along the Abukuma River. Iwasaki et al. [15] conducted numerical simulations of radiocesium distributions in the Abukuma river systems. Saegusa et al. [16] studied deposition of radiocesium on the floodplains along two rivers (Ukedo and Odaka Rivers) in Fukushima. Iwagami et al. [17] measured temporal changes of dissolved ${ }^{137} \mathrm{Cs}$ concentrations in groundwater and stream water in Yamakiya District in Fukushima. Kurikami et al. [18] made a simulation concerning to the behaviors of suspended sediments and ${ }^{137} \mathrm{Cs}$ at the Ogaki Dam reservoir on the Ukedo River, Fukushima, during the heavy rainfall. Eyrolle-Boyer et al. [19] collected suspended sediments, filtered water, and bottom sediments from six coastal rivers in Fukushima during low-flow conditions in November 2013. They derived significant correlations between radiocesium concentration and radiocesium inventories, liquid-solid partition coefficients $\mathrm{K}_{\mathrm{D}}$, and significant radiocesium transfer from contaminated forest litter to downstream rivers.

Up to now, information about the riverine radiocesium contamination in Fukushima was extensively accumulated as described above. However, long-term monitoring concerning the transport mechanism and temporal variation of radiocesium from land to river and from upstream to river mouth are needed for further research. After the Chernobyl accident, long-term radiological monitoring on riverine radiocesium contamination were conducted for five years or more in Ukraine [20-22], five rivers in Finland [23], and one river in Italy [24] and other European countries.

Minami-Soma City is located approximately $10-40 \mathrm{~km}$ to the north of the FDNPP, as shown in Figure 1. The eastern area on the coast of the Pacific Ocean was severely damaged by the tsunami, and the western area of the city joins the Abukuma mountain range, which was subjected to high levels of radioactive contamination. Most of the rivers in the Minami-Soma City originate from the Abukuma mountain range. Expansion of radiocesium contamination through the rivers is one of the serious concern of residents. Radiological monitoring of the river water is important for the daily life of residents along the watershed, and for irrigation of agriculture.

The purpose of the present work is to clarify the radiocesium contamination level and temporal variation of radioactive contamination along five rivers, through radiological surveys of sediments and river water during 2012-2016. We have previously performed groundwater monitoring in Minami-Soma City [25] and have observed ${ }^{137} \mathrm{Cs}$ in groundwater, which was also of serious concern for residents. The present work reports the results of long-term monitoring for five rivers after the FDNPP accident, and estimates of the effective half-lives of radiocesium decrease in each river are estimated. The accumulation of radiocesium over the floodplains at downstream areas was also observed as a result of long-term monitoring. 


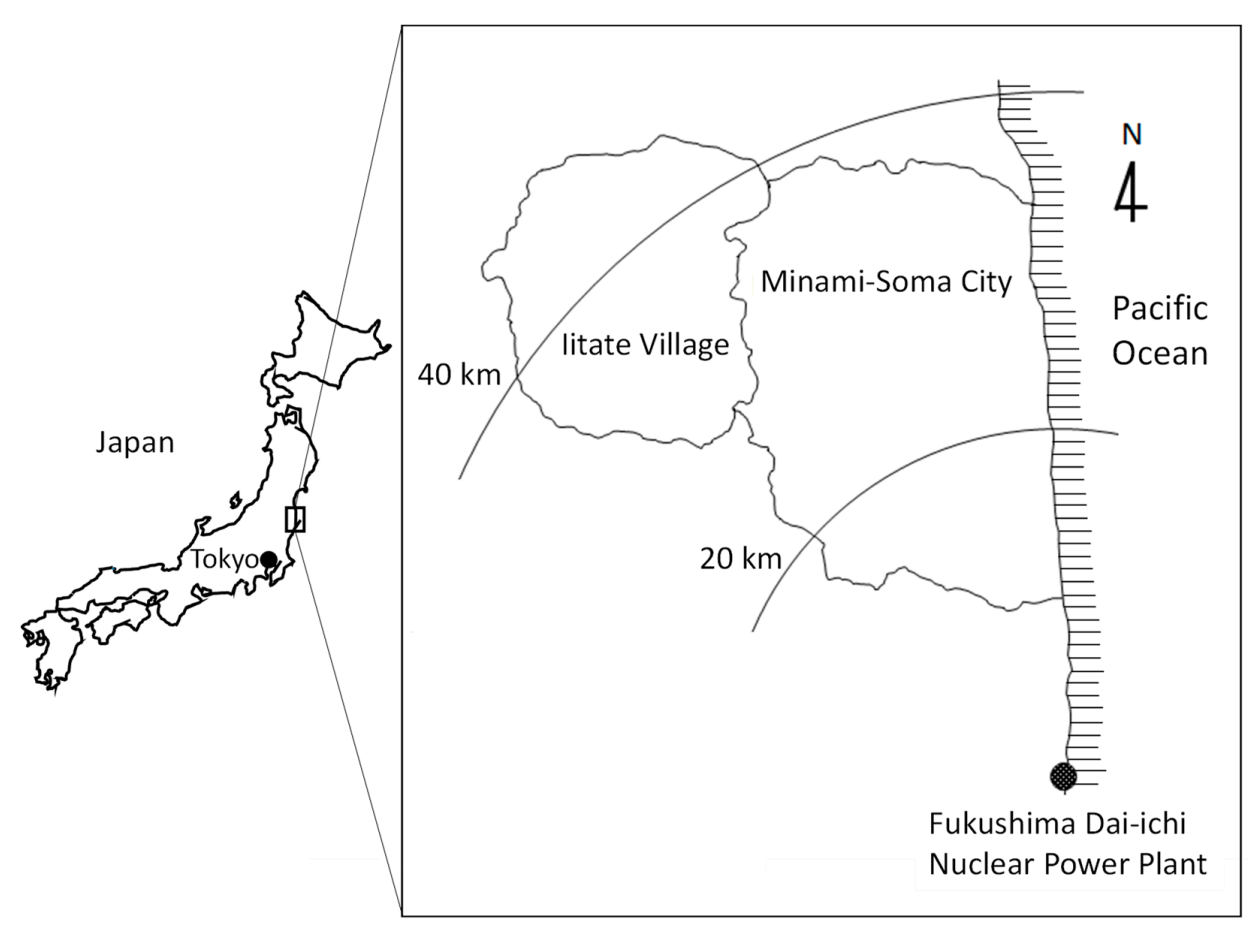

Figure 1. Locations of the Minami-Soma City and the Iitate Village from the FDNPP.

\section{Materials and Methods}

\subsection{Study Sites and Sampling}

Locations of rivers and sampling sites are shown in Figure 2. Color-coded ${ }^{137}$ Cs deposition $\left(\mathrm{Bq} \cdot \mathrm{m}^{-2}\right)$ were obtained by aircraft monitoring [7] normalized to 2 July 2011.

There are four major rivers in Minami-Soma City: the Odaka, the Ohta, the Niida, and the Mano Rivers. The Mizunashi River is a tributary stream that joins to the Niida River. These rivers are 12-16 km long from the upstream to the river mouth and flow into the Pacific Ocean except the Niida River, which starts from the Iitate Village, passing through about $40 \mathrm{~km}$ long, and it finally flows into the Pacific Ocean. It is noted that rivers in Ukraine are more than $400 \mathrm{~km}$ and about $160-200 \mathrm{~km}$ in Europe, which are longer than present rivers in Fukushima.

Sediment and river water were sampled from five or four sampling sites at the river side beneath the bridges during 2012 to 2016. Sampling sites at the N4 site of the Niida River and the P4 site of the Mizunashi River were added in 2013, and at the P1 site of the Mizunashi River in 2014. The N3 sampling site on the Niida River was changed to the N3' site in 2013 for easier access. These river systems include three dams; the Yokogawa Dam on the Ohta River, the Takanokura Dam on the Mizunashi River, and the Mano Dam on the Mano River, which were constructed for irrigation and flood prevention.

Since the Niida River starts from the Iitate Village where high radioactive contamination was observed, sediments and water samples were once performed in September 2012 in the Iitate Village at sampling sites $\mathrm{Q}_{1}-\mathrm{Q}_{4}$ along the Niida River and $\mathrm{R}_{1}-\mathrm{R}_{4}$ along the tributary stream of the litoi River as shown in Figure 2.

River sediments ( $\sim 300 \mathrm{~g}$ ) were collected from $20 \mathrm{~cm} \times 20 \mathrm{~cm}$ areas to a depth of $3 \mathrm{~cm}$ with a small plastic shovel covering the sand surface by hand so as not to disturb the sediment layer. The sampling was performed at the central region of the river channel or near the edge of the river mouth. Surface river water was also collected directly in a polypropylene bottle $(\sim 1 \mathrm{~L})$. Sampling was conducted on normal flow days between October and December to avoid heavy rainfall and the typhoon season in Japan. It is well known that radiocesium transport occurs after heavy rainfall. 


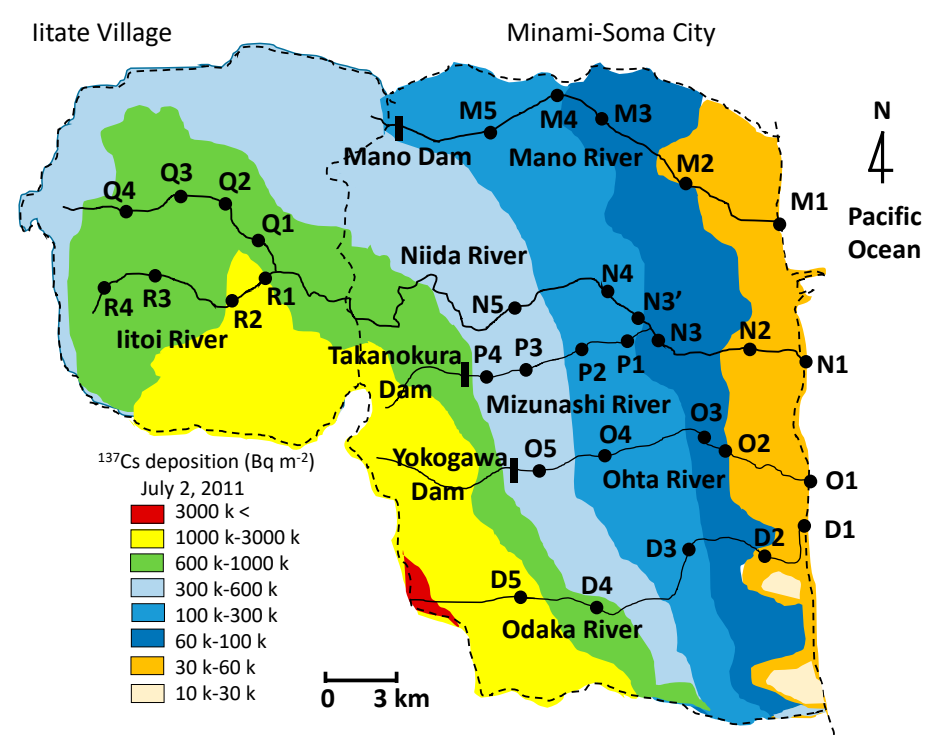

Figure 2. River sampling sites in the Minami-Soma City and the Iitate Village. Colors indicate the initial ${ }^{137}$ Cs deposition normalized on 2 July 2011 [7].

Nagao et al. [26] performed water sampling at the Natsui River and the Same River (sampling sites were about $40 \mathrm{~km}$ and $58 \mathrm{~km}$ to the south of the FDNPP, respectively) in September 2011. They reported that heavy rainfall after typhoon increased ${ }^{134} \mathrm{Cs}$ and ${ }^{137} \mathrm{Cs}$ concentrations in river water to $0.85 \mathrm{~Bq} \cdot \mathrm{L}^{-1}$ in high flow conditions, whereas they were $0.009-0.098 \mathrm{~Bq} \cdot \mathrm{L}^{-1}$ under normal flow conditions.

\subsection{Sample Preparation and Gamma-Ray Measurement}

Sediments were dried at $100{ }^{\circ} \mathrm{C}$ for about $24 \mathrm{~h}$ in a drying oven, and thereafter passed through a sieve with $2 \mathrm{~mm}$ openings to remove pebbles or hay, and mixed well. Sediments were packed into a polypropylene container (PP-U9, As one Co. Ltd., Japan, $50 \mathrm{~mm}$ diameter $\times 25 \mathrm{~mm}$ high) to a height of $20 \mathrm{~mm}$, weighing 50-60 g. Gamma-ray measurements were conducted using a low-background Ge detector (GEM-110225, EG\&G Ortec, Gaithersburg, MD, USA) in 2012. A new Ge detector (GEM 30-70, EG\&G Ortec, Gaithersburg, MD, USA) was utilized for samples collected in 2013-2016.

The radiocesium concentration in dissolved, and particulate components in river water are usually separated using a $0.45 \mu \mathrm{m}$ membrane filter. Then, the radiocesium in dissolved component is concentrated by several methods such as evaporation [27], co-precipitation [28-30], and Prussian blue-impregnated ion-exchange methods [31]. In the present work, we have applied a simple evaporation method to unfiltered water sample and radiocesium concentration was determined by measuring gamma-ray using a well-type Ge detector which has high sensitivity for small amount of samples. This method was previously utilized to determine uranium and radium concentrations in groundwater [32]. Unfiltered water sample (1 L) was measured accurately with a volumetric flask, and dried on a $250 \times 250 \times 2 \mathrm{~mm}$ Teflon sheet-lined steel tray on a hot plate at $120^{\circ} \mathrm{C}$ for about $6 \mathrm{~h}$. After drying process, the Teflon sheet was rolled up to a $13 \mathrm{~mm}$ diameter $\times 40 \mathrm{~mm}$ long size and pushed into a polyethylene tube. Gamma-ray measurements were performed using a low-background well-type Ge detector (GWL 120230-S, EG\&G Ortec) which has a well port of $14 \mathrm{~mm}$ diameter $\times 40 \mathrm{~mm}$ deep. This well-type Ge detector was equipped with an anticoincidence system composed of plastic scintillators, to reduce the cosmic-ray background level [33]. The typical gamma-ray measuring time was $80,000 \mathrm{~s}$.

The detection efficiencies of three Ge detectors were determined using a set of volume calibration sources (code No. MX033U8PP) manufactured by the Japan Radioisotope Association (JRIA). The detection efficiencies were previously reported, taking into account the coincidence-summing effect for ${ }^{134} \mathrm{Cs}$ and self-absorption [34]. The detection limits of the present Ge spectrometers for the 
${ }^{137} \mathrm{Cs}$ measurements were $5 \mathrm{~Bq} \cdot \mathrm{kg}^{-1}$ for sediment with Ge detectors, and $2 \mathrm{~m} \mathrm{~Bq} \cdot \mathrm{L}^{-1}$ for water with the well-type Ge detector.

\subsection{Particle Size Distribution and ${ }^{137}$ Cs Concentration in Sediment}

The relationship between the ${ }^{137} \mathrm{Cs}$ concentration and the particle size of sediments was investigated for sediment samples collected from the Odaka River in 2015. Using a set of sieves (model K50-1780, Narika Co. Ltd., Japan), sediment samples at D5, D2, and D1 sites on the Odaka River were fractionated into seven particle sizes (>6 mm, 6-4 mm, 4-2 mm, 2-1 mm, 1-0.5 mm, $0.5-0.25 \mathrm{~mm},<0.25 \mathrm{~mm}$ ). The masses of each particle size were measured and the ${ }^{137} \mathrm{Cs}$ concentrations in each fractionation were determined by gamma-ray measurements.

\subsection{Air Dose Rate Survey over Downstream Floodplains}

During sediment and river water sampling, it was noted that the air dose rate was much higher over the floodplains compared with the land surface around the sampling site, reflecting radiocesium accumulation on the floodplains. Radiocesium contamination was investigated by measuring the air dose rate distribution over the floodplain and ${ }^{137} \mathrm{Cs}$ depth profile in downstream areas. The floodplain at the Kinoene Bridge (D2 site) on the Odaka River and cross sectional view along the bridge are shown in Figure 3.

The Kinoene Bridge is $124 \mathrm{~m}$ long with floodplains of $30 \mathrm{~m}$ wide on the right side (B-C) and $35 \mathrm{~m}$ wide on the left side (D-F), and the river channel is $10 \mathrm{~m}$ wide. The air dose rate along the riverbed was surveyed on 27 September 2016 by using a mobile dosimeter GeoGamma-220 manufactured by Geosense Co. Ltd. Japan. This dosimeter measures the air dose rate with a $2^{\prime \prime}$ diameter $\times 2^{\prime \prime}$ long $\mathrm{NaI}(\mathrm{Tl})$ scintillator, and Global Positioning System data at $1 \mathrm{~s}$ intervals, and records integrated gamma-ray spectral data. The air dose rate measurements were conducted by holding the GeoGamma-220 $1 \mathrm{~m}$ above the ground and walking over the slope face and the floodplain along A-C and D-F in Figure 3.

Soil core sampling to a depth $30 \mathrm{~cm}$ were performed at the S1 and S2 sites over the floodplain shown in Figure 3. Soil core samples were separated every $5 \mathrm{~cm}$ from the surface and ${ }^{137} \mathrm{Cs}$ concentration was measured.

(a)
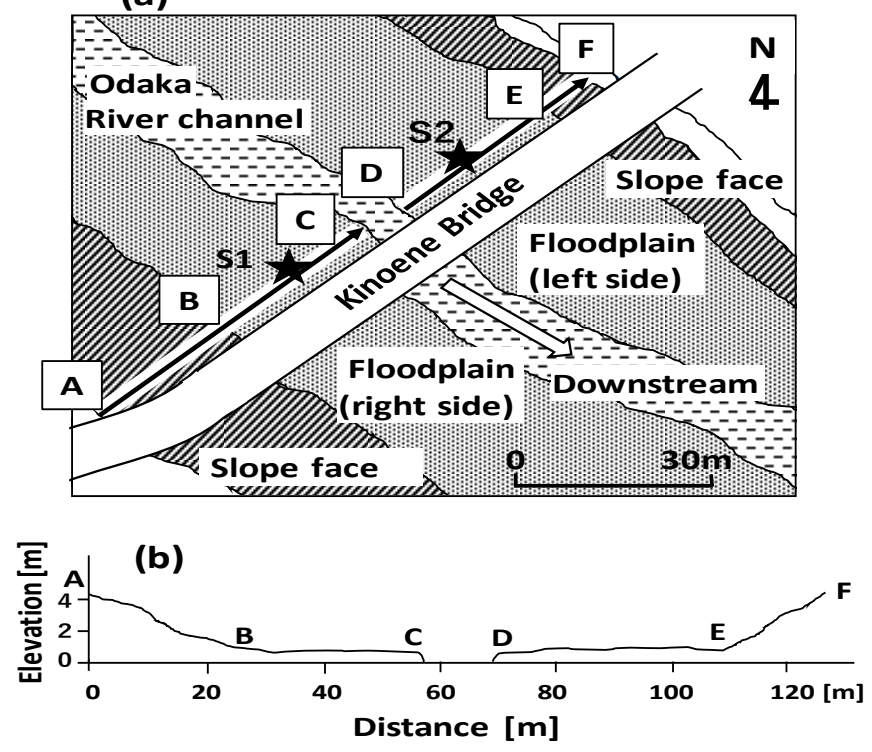

Figure 3. (a) Horizontal view around the Kinoene Bridge (D2 site) on the Odaka River. Air dose rates were measured along $\mathrm{A}-\mathrm{C}$ and D-F over the floodplain. Core samples were taken at S1 and S2 sites. (b) Cross sectional view along the A-F direction of the Odaka River. 


\section{Results}

\subsection{River Sediments in Minami-Soma City}

Radioactive concentrations of ${ }^{137} \mathrm{Cs}$ and ${ }^{134} \mathrm{Cs}$ in sediments sampled from five rivers during 2012-2016 are given in Table 1 . The ${ }^{137} \mathrm{Cs}$ and ${ }^{134} \mathrm{Cs}$ concentrations in sediments were generally high at upstream areas, and gradually decreased at downstream areas. Because the half-life of ${ }^{134} \mathrm{Cs}$ is much shorter than that of ${ }^{137} \mathrm{Cs}$, only the ${ }^{137} \mathrm{C}$ s results are discussed in this work. To compare the radioactive contamination levels and temporal changes of the ${ }^{137} \mathrm{Cs}$ concentrations, the concentrations in sediments at five sampling sites were averaged for each year. Since sampling was not performed at the P1 and the P4 sites in 2012 and the P1 site in 2013 on the Mizunashi River, the Mizunashi River was excluded from the comparison with other rivers. In the case of the Niida River, sampling at N4 site was not done in 2012, and the data at the four sampling sites except N4 were averaged. The results are shown in Figure $4 \mathrm{a}$. Temporal changes of averaged ${ }^{137} \mathrm{Cs}$ concentrations in sediments were observed for all rivers during 2012-2016.

\subsection{River Water}

Radioactive concentrations of ${ }^{137} \mathrm{Cs}$ and ${ }^{134} \mathrm{Cs}$ in unfiltered river water during 2012-2016 are given in Table 2. The results of river mouth samples were not included in the table because the ${ }^{137} \mathrm{Cs}$ and ${ }^{134} \mathrm{C}$ s concentrations were low, and they were a mixture of river water and sea water containing salt. The averaged ${ }^{137} \mathrm{C}$ s concentrations in unfiltered river water for each year are shown in Figure $4 \mathrm{~b}$. Temporal changes of the ${ }^{137}$ Cs concentration in river water were observed, similar to the sediments.
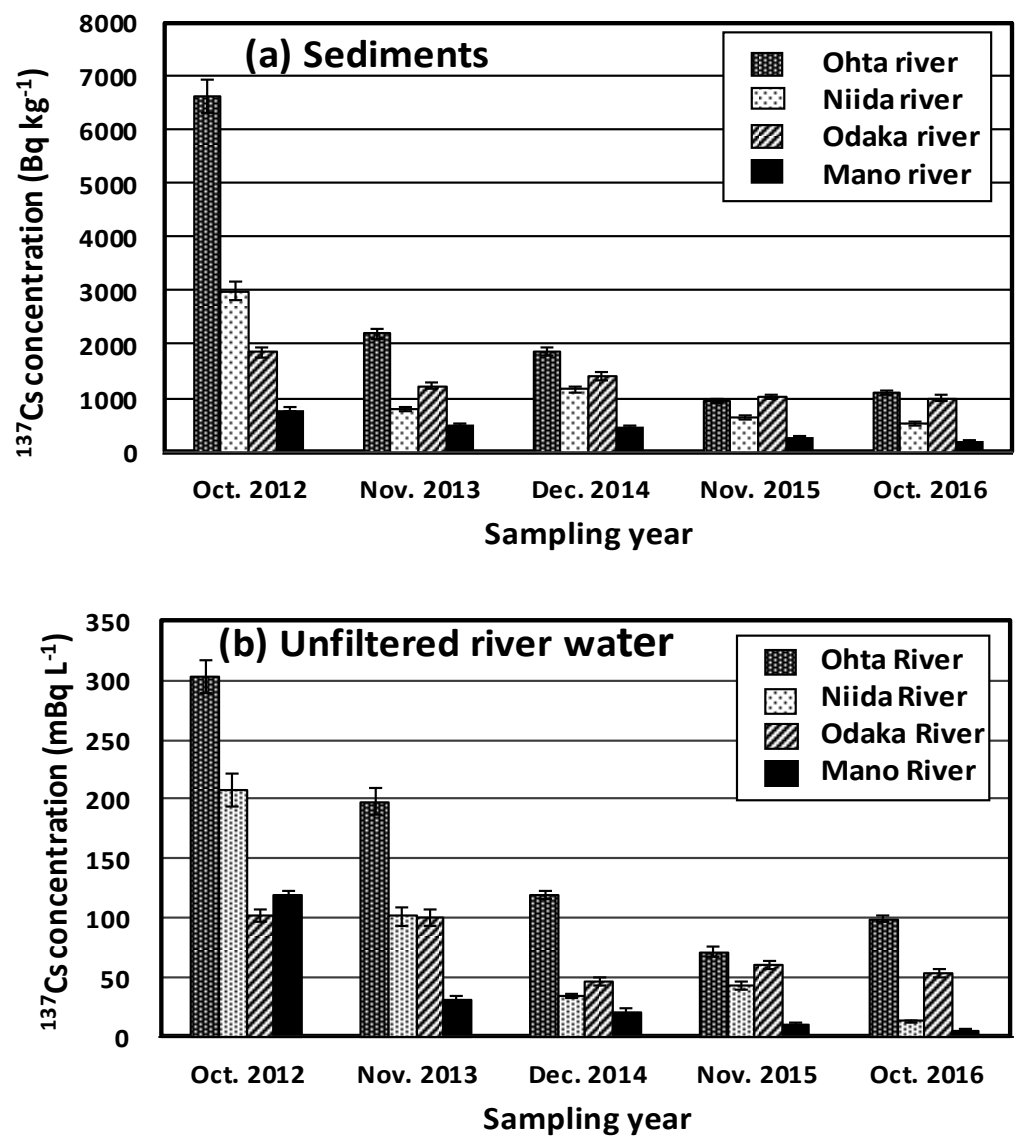

Figure 4. (a) Temporal decrease of average concentration of ${ }^{137} \mathrm{Cs}$ in sediments for the four rivers in 2012-2016. (b) Temporal decrease of average concentration of ${ }^{137}$ Cs in unfiltered river water for the four rivers in 2012-2016. 
Table 1. Concentrations of ${ }^{137} \mathrm{Cs}$ and ${ }^{134} \mathrm{Cs}$ in river sediments sampled from five rivers in the Minami-Soma City during 2012-2016. (Units: Bq. $\mathrm{kg}{ }^{-1}$ ).

\begin{tabular}{|c|c|c|c|c|c|c|c|c|c|c|c|}
\hline \multirow{2}{*}{ River } & \multirow{2}{*}{ Site } & \multicolumn{2}{|c|}{ October 2012} & \multicolumn{2}{|c|}{ November 2013} & \multicolumn{2}{|c|}{ December 2014} & \multicolumn{2}{|c|}{ November 2015} & \multicolumn{2}{|c|}{ October 2016} \\
\hline & & ${ }^{137} \mathrm{Cs}$ & ${ }^{134} \mathrm{Cs}$ & ${ }^{137} \mathrm{Cs}$ & ${ }^{134} \mathrm{Cs}$ & ${ }^{137} \mathrm{Cs}$ & ${ }^{134} \mathrm{Cs}$ & ${ }^{137} \mathrm{Cs}$ & ${ }^{134} \mathrm{Cs}$ & ${ }^{137} \mathrm{Cs}$ & ${ }^{134} \mathrm{Cs}$ \\
\hline \multirow{5}{*}{ Odaka } & D5 & $3561(252)$ & $2126(151)$ & $2655(188)$ & $1019(73)$ & 2651(188) & $806(58)$ & $2499(177)$ & $560(40)$ & $2915(207)$ & $560(40)$ \\
\hline & D4 & $2349(166)$ & 1387(99) & $2737(194)$ & $1235(88)$ & $3151(224)$ & $905(65)$ & $1717(122)$ & $377(22)$ & $1179(84)$ & $377(22)$ \\
\hline & D3 & $2445(173)$ & 1457(103) & $542(39)$ & $241(17)$ & $828(59)$ & $246(18)$ & $573(41)$ & $124(9)$ & $722(52)$ & $124(9)$ \\
\hline & D2 & $231(16)$ & 141(10) & 191(14) & $83(6)$ & $120(9)$ & $35(3)$ & $290(21)$ & $61(5)$ & 131(10) & $61(5)$ \\
\hline & D1 & $650(46)$ & $402(29)$ & $20(2)$ & $7(1)$ & 206(15) & $64(5)$ & $27(2)$ & $\mathrm{ND}^{\mathrm{a}}$ & $10(2)$ & ND \\
\hline \multirow{5}{*}{ Ohta } & $\mathrm{O} 5$ & $18,216(1288)$ & $9639(682)$ & $7221(511)$ & $3349(237)$ & $2904(206)$ & $882(63)$ & $2357(167)$ & $528(38)$ & $2494(177)$ & $423(30)$ \\
\hline & $\mathrm{O} 4$ & $10,591(749)$ & $5602(396)$ & 1875(133) & $863(61)$ & $2372(168)$ & $728(52)$ & $1259(90)$ & 258(19) & 1694(120) & $283(21)$ \\
\hline & $\mathrm{O} 3$ & $2446(173)$ & 1752(124) & $1615(115)$ & 751(54) & $1697(121)$ & $520(37)$ & $580(42)$ & $127(10)$ & $749(54)$ & $115(9)$ \\
\hline & $\mathrm{O} 2$ & $1782(126)$ & $1284(91)$ & $244(18)$ & $111(8)$ & $607(44)$ & $189(14)$ & $404(29)$ & $90(7)$ & $432(31)$ & $66(6)$ \\
\hline & $\mathrm{O} 1$ & $108(8)$ & $71(5)$ & $25(2)$ & $10(1)$ & $56(5)$ & $17(2)$ & $41(4)$ & $8(1)$ & $115(9)$ & $14(2)$ \\
\hline \multirow{5}{*}{ Niida } & N5 & $9129(646)$ & $6730(479)$ & $1939(138)$ & $874(62)$ & $2353(167)$ & $734(52)$ & $1758(124)$ & $434(31)$ & 1677(119) & $276(29)$ \\
\hline & $\mathrm{N} 4$ & - & - & $956(68)$ & $431(31)$ & $1890(134)$ & $589(42)$ & $478(34)$ & $116(9)$ & 187(14) & $29(3)$ \\
\hline & N3 & $1607(114)$ & $1170(83)$ & $515(37)$ & $228(17)$ & $1993(142)$ & $621(44)$ & $428(31)$ & $112(9)$ & $178(13)$ & $28(3)$ \\
\hline & N2 & $1072(76)$ & $858(61)$ & 659(47) & $303(22)$ & $308(22)$ & $90(7)$ & $372(27)$ & $86(6)$ & 184(13) & $29(2)$ \\
\hline & N1 & $157(11)$ & $123(9)$ & $84(7)$ & $35(3)$ & $21(2)$ & $7(1)$ & ND & ND & $11(2)$ & ND \\
\hline \multirow{4}{*}{ Mizunashi } & $\mathrm{P} 4$ & - & - & $12,348(874)$ & $2219(157)$ & $10,820(766)$ & $3782(268)$ & $6339(449)$ & $1579(112)$ & $3979(282)$ & $686(49)$ \\
\hline & P2 & $1869(132)$ & $1360(96)$ & $3406(241)$ & $1565(111)$ & 2049(146) & $680(49)$ & $1625(319)$ & $405(29)$ & $506(36)$ & $80(6)$ \\
\hline & P1 & - & - & - & - & $1320(90)$ & $453(33)$ & $809(58)$ & 190(14) & $421(30)$ & $68(5)$ \\
\hline & M5 & $664(47)$ & $410(29)$ & 1023(73) & $364(27)$ & $569(41)$ & 164(12) & $340(24)$ & $68(6)$ & 464(33) & $73(6)$ \\
\hline \multirow{4}{*}{ Mano } & M4 & $1423(101)$ & $890(63)$ & 196(15) & $68(6)$ & $592(42)$ & $176(13)$ & $302(22)$ & $60(5)$ & $244(18)$ & $39(4)$ \\
\hline & M3 & $1192(84)$ & $734(52)$ & $1048(75)$ & $387(28)$ & $835(60)$ & $246(18)$ & 190(14) & $35(3)$ & $207(15)$ & $35(3)$ \\
\hline & M2 & 231(16) & $142(10)$ & $121(9)$ & $41(4)$ & $227(17)$ & $66(9)$ & 263(19) & $52(5)$ & $96(7)$ & $16(2)$ \\
\hline & M1 & $419(30)$ & 264(19) & $44(4)$ & $44(4)$ & $34(3)$ & $10(2)$ & - & - & $32(3)$ & ND \\
\hline
\end{tabular}


Table 2. Concentrations of ${ }^{137} \mathrm{Cs}$ and ${ }^{134} \mathrm{Cs}$ in unfiltered river water sampled in the Minami-Soma City during 2012-2016. (Units: Bq. $\mathrm{L}^{-1}$ ).

\begin{tabular}{|c|c|c|c|c|c|c|c|c|c|c|c|}
\hline \multirow{2}{*}{ River } & \multirow{2}{*}{ Site } & \multicolumn{2}{|c|}{ October 2012} & \multicolumn{2}{|c|}{ November 2013} & \multicolumn{2}{|c|}{ December 2014} & \multicolumn{2}{|c|}{ November 2015} & \multicolumn{2}{|c|}{ October 2016} \\
\hline & & ${ }^{137} \mathrm{Cs}$ & ${ }^{134} \mathrm{Cs}$ & ${ }^{137} \mathrm{Cs}$ & ${ }^{134} \mathrm{Cs}$ & ${ }^{137} \mathrm{Cs}$ & ${ }^{134} \mathrm{Cs}$ & ${ }^{137} \mathrm{Cs}$ & ${ }^{134} \mathrm{Cs}$ & ${ }^{137} \mathrm{Cs}$ & ${ }^{134} \mathrm{Cs}$ \\
\hline \multirow{4}{*}{ Odaka } & D5 & 104(10) & 69(9) & $83(10)$ & $27(8)$ & $61(6)$ & $8(3)$ & $80(8)$ & $\mathrm{ND}^{\mathrm{a}}$ & $80(4)$ & ND \\
\hline & D4 & $114(11)$ & $51(8)$ & $92(13)$ & $24(9)$ & $38(5)$ & ND & $85(8)$ & $7(2)$ & $55(3)$ & ND \\
\hline & D3 & $89(9)$ & $48(7)$ & $102(14)$ & $29(11)$ & $50(6)$ & $11(4)$ & $53(6)$ & $8(6)$ & $52(3)$ & ND \\
\hline & D2 & $95(9)$ & $39(7)$ & 117(15) & $27(11)$ & $33(5)$ & $8(4)$ & $22(5)$ & ND & $25(1)$ & ND \\
\hline \multirow{4}{*}{ Ohta } & O5 & $446(38)$ & $287(28)$ & $265(27)$ & $81(21)$ & 203(8) & $55(7)$ & $116(11)$ & $33(8)$ & $119(6)$ & $10(1)$ \\
\hline & $\mathrm{O} 4$ & $290(27)$ & 205(18) & $258(28)$ & $85(17)$ & $126(12)$ & $30(6)$ & $70(7)$ & $25(8)$ & $113(6)$ & $13(1)$ \\
\hline & $\mathrm{O} 3$ & $233(20)$ & 171(17) & 154(18) & $35(14)$ & $76(8)$ & $17(4)$ & $50(6)$ & $15(7)$ & $77(4)$ & ND \\
\hline & $\mathrm{O} 2$ & $242(22)$ & 182(19) & $113(17)$ & $39(16)$ & $71(6)$ & $14(4)$ & $48(6)$ & ND & $88(4)$ & ND \\
\hline \multirow{4}{*}{ Niida } & N5 & $419(38)$ & $316(31)$ & $159(16)$ & $72(11)$ & $58(6)$ & $15(4)$ & $52(6)$ & ND & $10(1)$ & ND \\
\hline & N4 & - & - & $229(22)$ & $95(13)$ & $27(4)$ & ND & $56(5)$ & ND & $9(1)$ & ND \\
\hline & N3 & 110(13) & $75(8)$ & $58(8)$ & $30(7)$ & $29(4)$ & ND & $31(4)$ & ND & $13(1)$ & ND \\
\hline & $\mathrm{N} 2$ & 95(9) & $38(7)$ & $85(10)$ & $47(8)$ & 15(3) & ND & $47(7)$ & $11(6)$ & $15(7)$ & ND \\
\hline \multirow{4}{*}{ Mizunashi } & P4 & - & - & $222(21)$ & $78(12)$ & $108(10)$ & $68(15)$ & $137(9)$ & $36(8)$ & $63(3)$ & ND \\
\hline & P3 & $383(34)$ & $271(28)$ & $98(13)$ & $21(11)$ & $116(11)$ & $80(16)$ & $86(8)$ & $26(9)$ & $49(4)$ & ND \\
\hline & P2 & $140(14)$ & $118(14)$ & $138(14)$ & $63(11)$ & $74(7)$ & $39(12)$ & $53(5)$ & $8(4)$ & $42(2)$ & ND \\
\hline & P1 & - & - & - & - & $87(9)$ & $70(14)$ & $47(5)$ & $13(5)$ & $33(3)$ & ND \\
\hline \multirow{4}{*}{ Mano } & M5 & $109(7)$ & $44(2)$ & $38(5)$ & $14(5)$ & $31(4)$ & ND & $24(3)$ & ND & ND & ND \\
\hline & M4 & $166(7)$ & $81(4)$ & $28(5)$ & $11(7)$ & 15(3) & ND & $10(2)$ & ND & $7(2)$ & ND \\
\hline & M3 & $68(5)$ & $31(2)$ & $32(5)$ & ND & 21(3) & ND & ND & ND & $12(2)$ & ND \\
\hline & M2 & $132(8)$ & $60(3)$ & $24(5)$ & ND & 14(3) & ND & $7(3)$ & ND & ND & ND \\
\hline
\end{tabular}

a ND indicates under detection limit. 
Since unfiltered water sample was utilized for the ${ }^{137} \mathrm{Cs}$ measurement in the present work, the ${ }^{137} \mathrm{Cs}$ concentration might be higher compared to the dissolved component only. We compared the ${ }^{137} \mathrm{Cs}$ concentration in filtered/unfiltered, i.e., the dissolved component to the total amount for river water samples at D2 (the Odaka River), O2 (the Ohta River), N5 (the Niida River), and M5 (the Mano River) in 2015. The results are given in Table 3. The ratios were varied over $40-80 \%$ (58\% on average), which agree with the results of particulate fractions of $21-56 \%$ under normal flow conditions by Nagao et al. [26]. Eyrolle-Boyer et al. [19] measured the dissolved and particulate radiocesium fluxes to total (dissolved + particulate) radiocesium fluxes in the Mano, the Niida, the Ohta, the Odaka, and the Ukedo rivers in Nov. 2013, during conditions of low flow, and the dissolved fraction varied from 27 to $70 \%$ (52\% for all rivers). Our results agreed well with their results. Thus, the present ${ }^{137} \mathrm{Cs}$ concentration in unfiltered water might be $72 \%$ higher on average, compared to the dissolved component only.

Table 3. Ratios of ${ }^{137}$ Cs concentration in the filtered to the unfiltered component.

\begin{tabular}{ccc}
\hline River & Sampling Site & ${ }^{137}$ Cs Concentration Ratio Filtered/Unfiltered \\
\hline Odaka & D2 & $0.57 \pm 0.24$ \\
Ohta & O2 & $0.80 \pm 0.12$ \\
Niida & N5 & $0.57 \pm 0.10$ \\
Mano & M5 & $0.40 \pm 0.14$ \\
\hline
\end{tabular}

\subsection{Iitate Village}

Sediment and water sampling were performed in the Iitate Village in 2012. The results are shown in Figure 5a,b, respectively. The concentration in sediments and unfiltered river water were 2-9 $\mathrm{kBq} \cdot \mathrm{kg}^{-1}$ and $100-180 \mathrm{mBq} \cdot \mathrm{L}^{-1}$, respectively. In the case of the Minami-Soma City, a trend was present, with the concentration was generally high at the upstream area and gradually decreased downstream. However, such a trend was not observed in the sediment and river water in the Iitate Village.
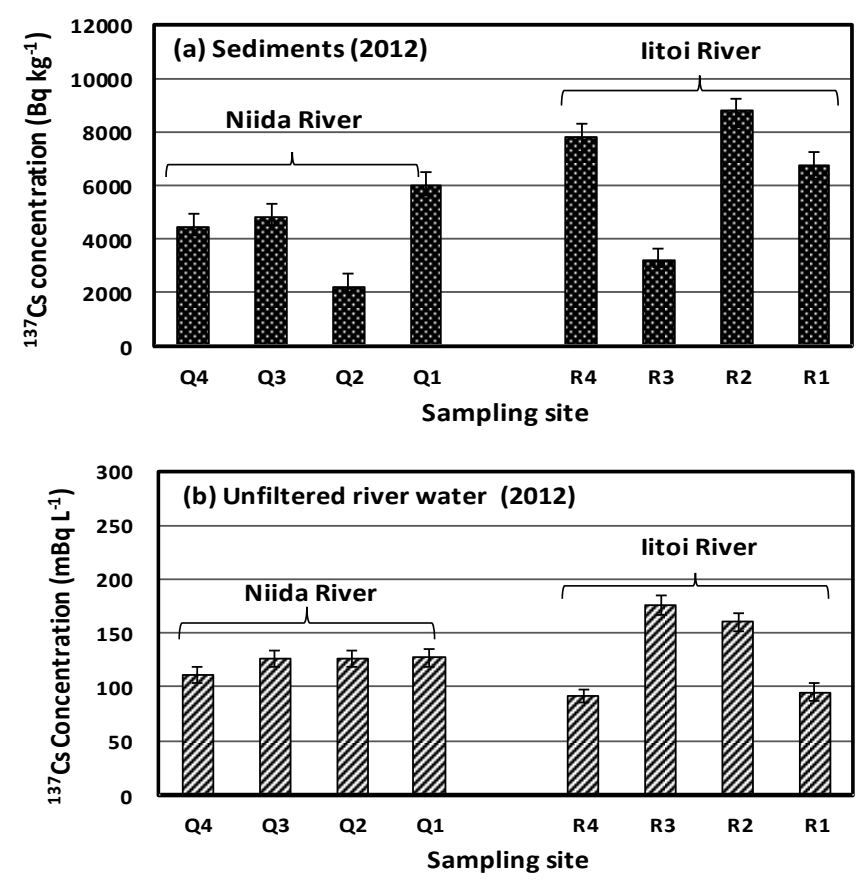

Figure 5. (a) ${ }^{137} \mathrm{Cs}$ concentration in sediments in the litate Village. (b) ${ }^{137} \mathrm{Cs}$ concentration in unfiltered river water in the Iitate Village. Sampling was performed in September 2012. 


\subsection{Particle Size Dependence of ${ }^{137}$ Cs Concentration in Sediment}

The particle size of sediments were separated into seven classes, and the weight fractions of each particle size was obtained at the D5, D2, and D1 sites on the Odaka River. The dependences of weight fraction on the particle size are shown in Figure 6. Weight fractions of the sediments at the upstream D5 site showed a maximum at 4-2 mm particles; the middle D2 site showed a maximum at $1.0-0.5 \mathrm{~mm}$, and the river mouth D1 showed a maximum at $<0.25 \mathrm{~mm}$. These results indicate that the weight fraction of small particle size increased at the downstream site.

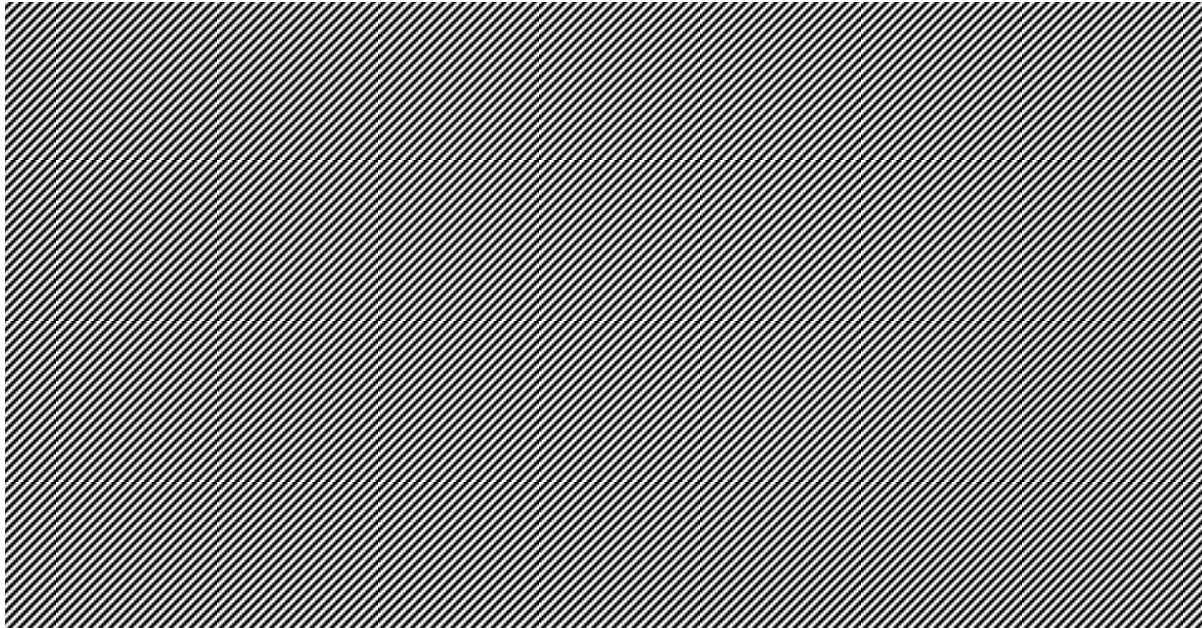

Figure 6. Particle size and weight fraction of sediments at three sampling sites D5, D2, D1 on the Odaka River.

The dependence of the ${ }^{137}$ Cs concentration on the particle size for D5 and the D2 sites are shown in Figure 7a. Since the ${ }^{137} \mathrm{Cs}$ concentration was low for all particle sizes at the D2 site, its concentration was multiplied by an arbitrary factor of 25 for comparison. The distribution pattern shown in Figure $7 \mathrm{a}$ indicates that the ${ }^{137} \mathrm{Cs}$ concentration increased as the particle size decreased, and such pattern was the same at the D5 and the D2 sites. The total amount of ${ }^{137} \mathrm{Cs}$ in each sample size could be obtained by the ${ }^{137} \mathrm{Cs}$ concentration multiplied by the weight fraction. The results are shown in Figure $7 \mathrm{~b}$. The maximum total amount of ${ }^{137} \mathrm{Cs}$ appeared at the particle size $4-2 \mathrm{~mm}$ for the D5 site and $1.0-0.5 \mathrm{~mm}$ for the $\mathrm{D} 2$ site. These results mean that the pattern of the ${ }^{137} \mathrm{Cs}$ concentration along a river, i.e., high upstream and gradually becoming low downstream, was not due to the weight fraction of small particle size, but due to the initial deposition of radiocesium.

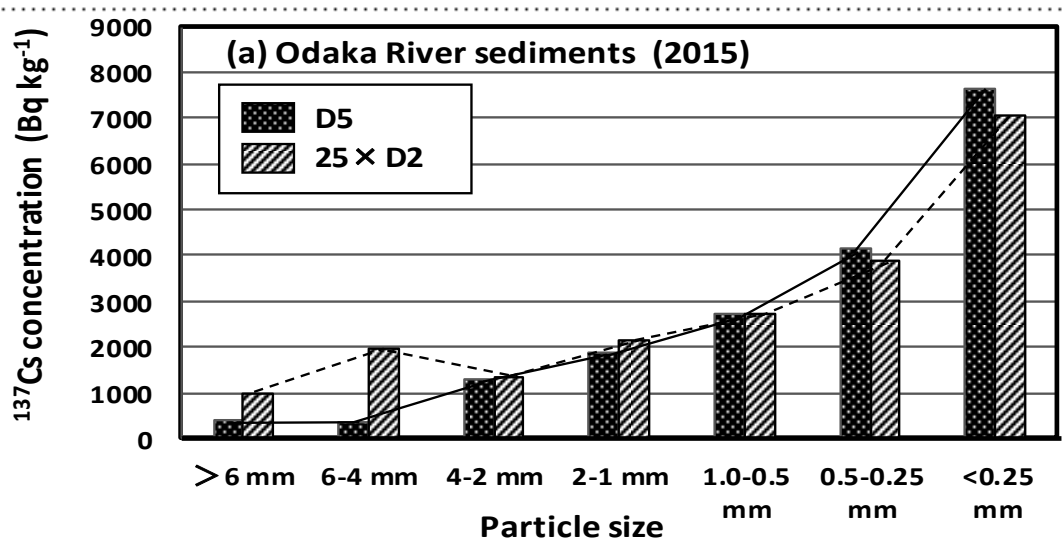

Figure 7. Cont. 


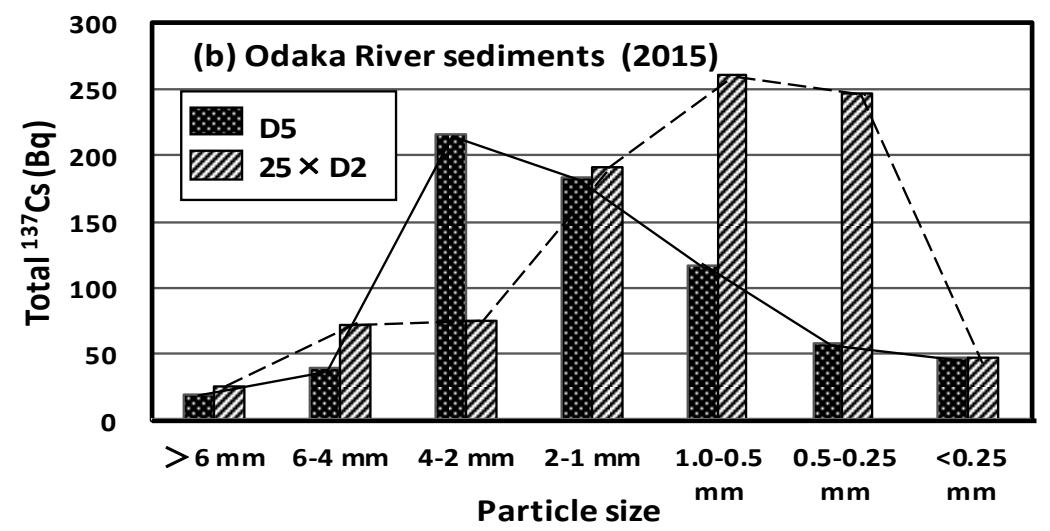

Figure 7. (a) ${ }^{137} \mathrm{Cs}$ concentration as a function of particle size at sampling sites D5 and D2 on the Odaka River. The concentration at D2 site was multiplied by a factor of 25 . (b) Total ${ }^{137}$ Cs distribution as a function of particle size at sampling sites D5 and D2 on the Odaka River. The concentration at the D2 site was multiplied by a factor of 25 .

\subsection{Air Dose Rate and ${ }^{137}$ Cs Depth Profile over the Floodplain}

The profiles of the air dose rate over the floodplains at the Kinoene Bridge (D2 site) along A-C and D-F directions are shown in Figure 8. The profiles were not uniform, but showed peaks of about $0.9 \mu \mathrm{Sv} \cdot \mathrm{h}^{-1}$ along the A-C direction, and $1.1 \mu \mathrm{Sv} \cdot \mathrm{h}^{-1}$ along the D-F direction, which were about one order of magnitude higher than the air dose rate of $0.1-0.2 \mu \mathrm{Sv} \cdot \mathrm{h}^{-1}$ for the land surfaces A and F. The profile reflected an accumulation of radiocesium over the floodplain.

Depth profiles of ${ }^{137} \mathrm{Cs}$ at S1 and S2 sites over the floodplain are shown in Figure 9. It was noted that the soil type of $\mathrm{S} 1$ core was sandy soil, and the $\mathrm{S} 2$ core was muddy soil. The ${ }^{137} \mathrm{Cs}$ concentration strongly depended on the soil type. The ${ }^{137} \mathrm{Cs}$ concentration was about $300 \mathrm{~Bq} \mathrm{~kg}{ }^{-1}$ at the surface of the $\mathrm{S} 1$ core, whereas it was 20,000 Bq. $\mathrm{kg}^{-1}$ at the surface of the S2 core. The depth profile at the S1 core showed a flat pattern from the surface to $30 \mathrm{~cm}$ in depth. On the other hand, the S2 core showed a much higher concentration up to a depth of about $15 \mathrm{~cm}$.
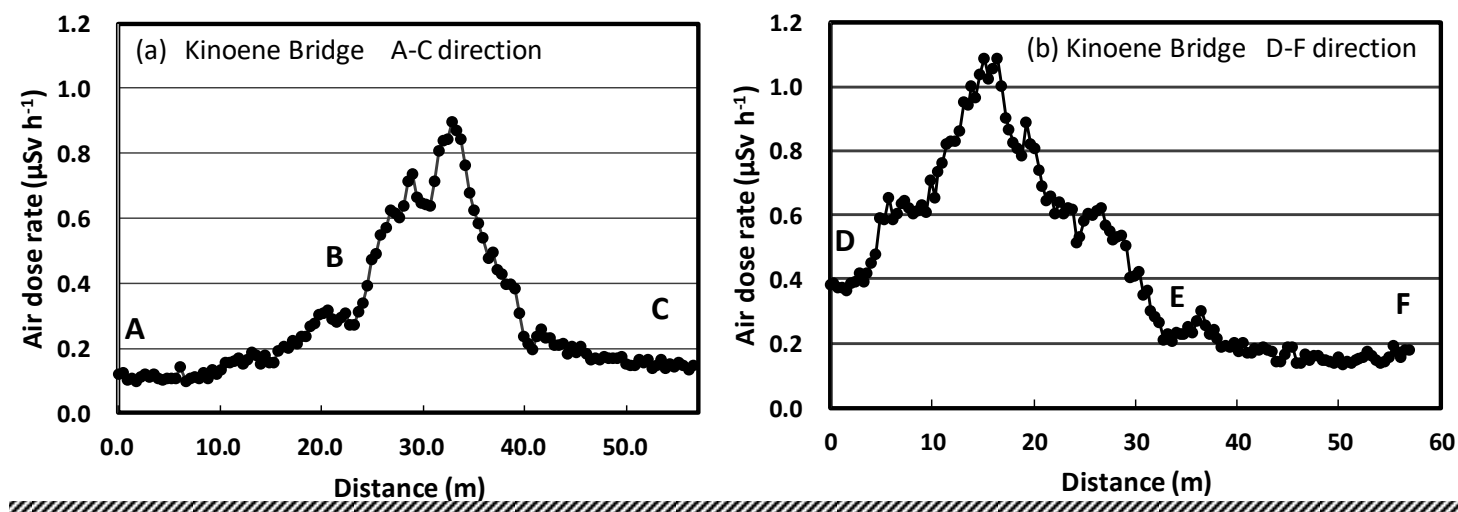

Figure 8. Profiles of the air dose rate over the floodplain at the Kinoene Bridge (D2 site) on the Odaka River. (a) Air dose rate along the A-C direction in Figure 3. (b) Air dose rate along the D-F direction in Figure 3. 

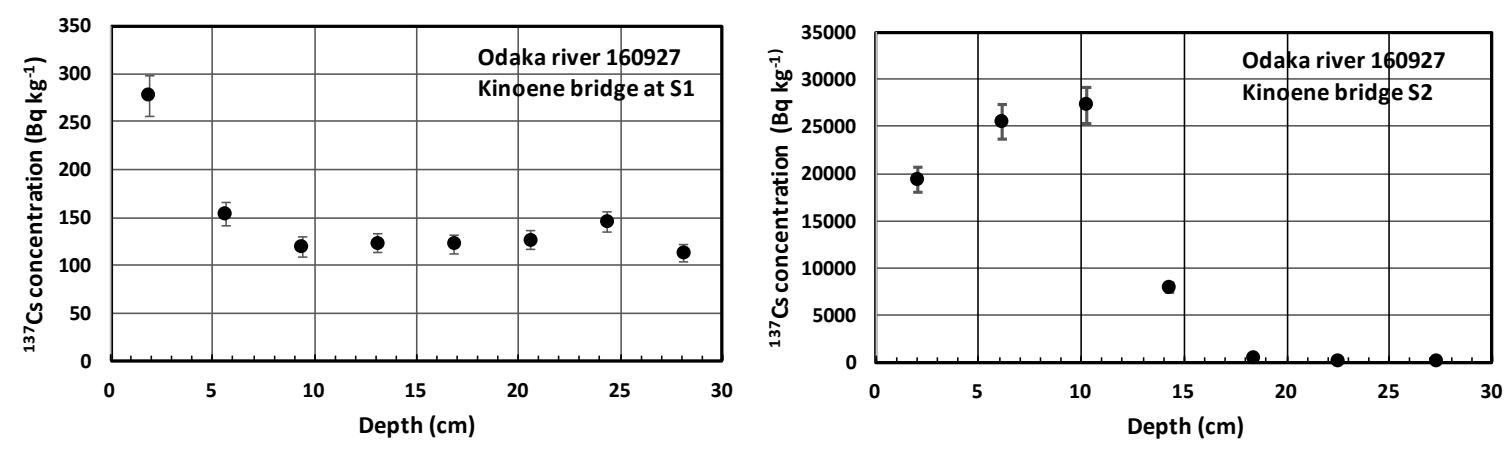

Figure 9. (a) ${ }^{137} \mathrm{Cs}$ depth profile over the floodplain at the Kinoene Bridge at the S1 site on the Odaka River. (b) ${ }^{137}$ Cs depth profile over the floodplain at the S2 site.

\section{Discussion}

\subsection{Initial Deposition of the ${ }^{137}$ Cs and Distribution Profile along the River}

According to the ${ }^{137} \mathrm{Cs}$ concentration in sediments along five rivers as given in Table 1, the ${ }^{137} \mathrm{Cs}$ concentration showed a profile where the concentrations were generally high upstream, and gradually decreased downstream. These profiles are not due to the particle size distribution. The results of particle size separation shows large size particles are dominant in the upstream and vice versa in the downstream. On the contrary, small size particles are minor components in the upstream and are dominant in the downstream. The ${ }^{137} \mathrm{Cs}$ concentration profile along a river is mainly related to the initial deposition (initial inventory) over the land, as shown by the color code in Figure 2. The upstream area of the Odaka, the Ohta, and the Mizunashi Rivers shows a high initial deposition of $1000-3000 \mathrm{kBq} \cdot \mathrm{m}^{-2}$ and it gradually decreases at the downstream area. In the case of the Niida River, the initial deposition of about $1000 \mathrm{kBq} \cdot \mathrm{m}^{-2}$ in the Iitate Village is as high as the levels in the Odaka, the Ohta, and the Mizunashi Rivers, and it gradually decreases in the downstream area in the Minami-Soma City. On the other hand, the initial deposition at the upstream area of the Mano River of $100-300 \mathrm{kBq} \cdot \mathrm{m}^{-2}$ is not so high compared to the other rivers. Thus the ${ }^{137} \mathrm{Cs}$ concentration shows no clear dependence on the sampling site.

\subsection{Temporal Decrease of ${ }^{137}$ Cs Concentration in Sediment and River Water}

Iwagami et al. [17] measured the dissolved ${ }^{137} \mathrm{Cs}$ component on three rivers at sites downstream of the catchments under normal flow conditions every two months during 2011-2013 in the Yamakiya District, Fukushima. They observed a rapid decrease of ${ }^{137} \mathrm{Cs}$ concentration during the initial flush until the end of 2011, with effective half-lives of $0.10-0.21 \mathrm{y}$, and thereafter, a slow decrease of ${ }^{137} \mathrm{Cs}$ as the second phase with effective half-lives of $0.69-1.5 \mathrm{y}$ in the three catchments.

Kurikami et al. [18] studied behaviors of suspended sediments and ${ }^{137} \mathrm{Cs}$ in the Ogaki Dam reservoir on the Ukedo River, Fukushima, during a heavy rainfall caused by the typhoon on 15 September 2013. Their simulation results were interpreted that the reservoir play a role to delay and buffer the transport of radiocesium in heavy rainfall events.

After Chernobyl accident, long-term radiological monitoring of river water were performed at two rivers, the Pripyat and the Dnieper Rivers, in Ukraine for 1986-2001 by Vakulovsky et al. [20] and five rivers in Finland for $1986-1996$ by Saxén and Ilus [23]. The ${ }^{137}$ Cs concentration decreased exponentially in the first 5-6 years, then it declined slowly. We have estimated the effective half-lives of the Pripyat and the Dnieper Rivers fitting with an exponential function:

$$
y=A_{0} \exp (-\lambda t)
$$


where $A_{0}\left(\mathrm{~Bq} \cdot \mathrm{kg}^{-1}\right)$ is an initial deposition, $\lambda\left(\mathrm{y}^{-1}\right)$ is annual decrease rate, and $t(\mathrm{y})$ is the elapsed time from initial deposition. The effective half-life is derived as $T_{e}=\ln 2 \lambda^{-1}$ using the annual decrease rate $\lambda$. The effective half-lives were 1.5-1.6 y for the Pripyat and the Dnieper Rivers in Ukraine. Two rivers in Finland, the Kymijohl and the Kokenmäenjoki Rivers, which were located in high radioactive contamination areas, were also fitted with an exponential function. The estimated effective half-lives were 1.1-1.0 y, similar to the case of Ukraine.

We have also estimated the effective half-lives of the ${ }^{137} \mathrm{Cs}$ decrease of sediments in Minami-Soma City shown in Figure 4a, with fitting with an exponential function. The results are given in Table 4. The annual decrease rates for sediment were $0.33-0.46 \mathrm{y}^{-1}$ and the associated effective half-lives were 1.5-2.1 y, except for the Odaka River which had a longer effective half-life of $4.7 \mathrm{y}$. The annual decrease rate and effective half-life were also estimated for the average concentration of ${ }^{137} \mathrm{Cs}$ in river water shown in Figure $4 \mathrm{~b}$. The results are also given in Table 4 . The effective half-lives were 0.9-2.1 y except for the Odaka River which had a longer effective half-life of 3.7 y.

Table 4. Estimation of initial deposition $A_{0}$, annual decrease rate $\lambda$ and effective half-life $T_{e}$ of sediment and river water in the Minami-Soma City.

\begin{tabular}{|c|c|c|c|c|c|c|}
\hline \multirow{2}{*}{ River } & \multicolumn{3}{|c|}{ Sediment } & \multicolumn{3}{|c|}{ River water } \\
\hline & $A_{0 w}\left(\mathrm{~Bq} \cdot \mathrm{kg}^{-1}\right)$ & $\lambda_{s}\left(\mathrm{y}^{-1}\right)$ & $T_{e}(\mathrm{y})$ & $A_{0 w}\left(\mathrm{mBq} \cdot \mathrm{L}^{-1}\right)$ & $\lambda_{w}\left(\mathrm{y}^{-1}\right)$ & $T_{e}(\mathrm{y})$ \\
\hline Odaka & 1990 & $0.15 \pm 0.04$ & $4.7 \pm 1.3$ & 121 & $0.19 \pm 0.09$ & $3.7 \pm 1.7$ \\
\hline Ohta & 8020 & $0.46 \pm 0.12$ & $1.5 \pm 0.4$ & 387 & $0.34 \pm 0.10$ & $2.1 \pm 0.6$ \\
\hline Niida & 3272 & $0.39 \pm 0.13$ & $1.8 \pm 0.6$ & 401 & $0.66 \pm 0.12$ & $1.0 \pm 0.2$ \\
\hline Mano & 1103 & $0.33 \pm 0.03$ & $2.1 \pm 0.2$ & 221 & $0.78 \pm 0.07$ & $0.9 \pm 0.1$ \\
\hline
\end{tabular}

The effective half-lives for the three dammed rivers agree with the second phase data are reported by Iwagami et al. [17]. As shown in Figure 2, the Ohta, the Mizunashi, and the Mano Rivers are dammed at upstream, and ${ }^{137} \mathrm{Cs}$ supplied from the Abukuma mountain range to the river has accumulated in the dam reservoir. Since present sampling sites were all located in the downstream area of the dams, the temporal ${ }^{137} \mathrm{Cs}$ decrease in sediments and river water is demonstrated with a single exponential function. In contrast, the Odaka River is not dammed upstream, thus, the ${ }^{137} \mathrm{Cs}$ decrease is represented not only by a simple exponential function, but an additional transfer component from the forest and the plain to the river might exist.

One possibility to represent the temporal decrease of ${ }^{137} \mathrm{Cs}$ on the Odaka River with two components is as follows:

$$
y=A_{0} \exp \left(-\lambda_{s} t\right)+B t \exp \left(-\lambda_{t} t\right)
$$

where $B$ and $\lambda_{t}$ are two additional parameters. Taking the exponential decrease component of $y=2200 \exp (-0.46 t)$, where the decrease rate $\lambda_{s}$ is the same value as the Ohta River, the transport component is obtained as $y=418 t \exp (-0.206 t)$ through fitting of the sediment data.

The temporal decrease ${ }^{137} \mathrm{Cs}$ on the Odaka River water was also fitted with two component functions similar to the sediments. Taking the exponential decrease component as $y=80 \exp (-0.34 t)$, the transfer component was estimated as $y=62 t \exp (-0.47 t)$. Thus, the ${ }^{137} \mathrm{Cs}$ in sediment and river water without dammed upstream indicate the existence of two components; one is a decrease component of the initial deposition, and another is a transfer component from the forests and plains to the river. The Niida River is not dammed upstream, but it passes a long watershed and many weirs for irrigation are installed. Therefore, the ${ }^{137} \mathrm{Cs}$ supplied at the sampling site N5 on the Niida River might be similar to other dammed rivers.

\subsection{Transport of Radiocesium along a River}

The mechanism of the radiocesium transport from upstream to downstream along a river system has been investigated by many authors. Evrard et al. [10] reviewed the fundamental process of radiocesium transfer from hillslopes to the Pacific Ocean, and pointed out that soil erosion is 
an important process for transporting radiocesium. Most radiocesium is attached to fine particles, and the most significant transfer occurs during major rainfall and runoff events. Iwasaki et al. [15] performed simulation calculations of sediment transfer on the Abukuma River and showed an accumulation of ${ }^{137} \mathrm{C}$ s over floodplains, suggesting that ${ }^{137} \mathrm{Cs}$ supplied from upstream by the washload would mostly reach the ocean directly. Saegusa et al. [16] performed detailed investigations of radiocesium deposition along the Odaka and the Ukedo Rivers. They reported high radiocesium concentrations over the floodplains and proposed a mechanism for ${ }^{137} \mathrm{Cs}$ transport and deposition.

In the present work, it has been shown that high concentrations of radiocesium in sediments at the upstream area in the Minami-Soma area were rapidly transported to the ocean with effective half-lives of 1.5-2.1 y. On the other hand, accumulation of ${ }^{137} \mathrm{Cs}$ over floodplains in the downstream occurred as a secondary contamination. The air dose rates were about $1.0 \mu \mathrm{Sv} \cdot \mathrm{h}^{-1}$ over the floodplains on the Odaka river, whereas the air dose rates at the land surface were about $0.1-0.2 \mu \mathrm{Sv} \cdot \mathrm{h}^{-1}$, as shown in Figure 8. According to the ${ }^{137} \mathrm{Cs}$ depth profiles of soil cores measured at right and left side floodplains, the surface ${ }^{137} \mathrm{Cs}$ concentration reached to $20,000 \mathrm{~Bq} \cdot \mathrm{kg}^{-1}$ in muddy soil, whereas ${ }^{137} \mathrm{Cs}$ concentration in sediments in the river channel was about $10 \mathrm{~Bq} \cdot \mathrm{kg}^{-1}$.

The accumulation of radiocesium over the floodplain is caused by floods due to heavy rainfall during the typhoon and rainy seasons in Japan. Flooding occurs several times every year in the Minami-Soma area, and the water level rises to cover the floodplains where tall plants are growing. The flood velocity is decelerated over the floodplains and the plants help to retain the clay or mud over the floodplains. After the flood, the water level returns to normal and the radiocesium included in sand or mud remains on the floodplains. Therefore, most of radiocesium supplied in the river from the contaminated upstream area are transported to ocean directly, but accumulation occurs over the floodplains in the downstream where initial contamination was low.

\section{Conclusions}

The ${ }^{137} \mathrm{Cs}$ concentrations in sediment and river water were measured in Minami-Soma City during 2012-2016 under normal flow condition. The sampling sites on each river spanned from the upstream area to the river mouth. The ${ }^{137} \mathrm{Cs}$ concentration in sediment was highest at upstream sites and slowly decreased to downstream sites. The ${ }^{137} \mathrm{Cs}$ concentration in the river water showed a similar pattern as the sediments. The average ${ }^{137} \mathrm{Cs}$ concentration in sediments and river water for each river showed a rapid temporal decrease during the monitoring period. The annual decrease rate $\lambda$ and the associated effective half-life $T_{e}$ were determined to be 1.5-2.1 y for sediments, and 0.9-2.1 y for river water for rivers with dams. These effective half-lives were similar to those observed in the Ukraine and Finland rivers after the Chernobyl accident. On the Odaka River, which is an undammed river, the effective half-life was $4.7 \mathrm{y}$ for sediments and $3.7 \mathrm{y}$ for river water. The longer effective half-lives probably indicated a direct transfer of ${ }^{137} \mathrm{Cs}$ from forests and plains to rivers.

The ${ }^{137} \mathrm{Cs}$ concentration in riverbed is low in the downstream areas; however, accumulation of radiocesium over the floodplains are observed as a secondary radioactive contamination. The present findings should be taken into consideration for future decontamination involving rivers.

Author Contributions: K.S. and Y.S. planned and performed all sampling. W.I.N. joined the present work and performed sampling with co-workers. The manuscript was written by K.S. with support from all co-authors.

Funding: This research received no external funding.

Acknowledgments: The authors sincerely appreciate the cooperation of Toshihiro Sakurai during sample collection in this study. This work was supported by The Japan Association of National Universities during 2011-2013, and the Leader Education Program for the Renaissance from Radiation Disaster funded by the Ministry of Education, Culture, Science and Technology.

Conflicts of Interest: The authors declare no conflict of interest. 


\section{References}

1. Steinhauser, G.; Brandl, A.; Johnson, T.E. Comparison of the Chernobyl and Fukushima nuclear accidents: A review of the environmental impacts. Sci. Total Environ. 2014, 470, 800-817. [CrossRef] [PubMed]

2. Ministry of Education, Culture, Sports, Science and Technology (MEXT). Monitoring Information of Environmental Radioactivity Level about Strontium Concentration, 2012, Japanese. Available online: http:/ / radioactivity.mext.go.jp/ja / (accessed on 10 October 2012).

3. Endo, S.; Kimura, K.; Takatsuji, T.; Nanasawa, K.; Imanaka, T.; Shizuma, K. Measurement of soil contamination by radionuclides due to the Fukushima Dai-ichi Nuclear Power Plant accident and associated estimated cumulative external dose estimation. J. Environ. Radioact. 2012, 111, 18-27. [CrossRef] [PubMed]

4. Shozugawa, K.; Nogawa, N.; Matsuo, M. Deposition of fission and activation products after the Fukushima Dai-ichi Nuclear Power Plant accident. Environ. Pollut. 2012, 163, 243-247. [CrossRef] [PubMed]

5. Saito, K.; Tanihata, I.; Fujiwara, M.; Saito, T.; Shimoura, S.; Otsuka, T.; Onda, Y.; Hoshi, M.; Ikeuchi, Y.; Takahashi, F.; et al. Detailed deposition density maps constructed by large-scale soil sampling for gamma-ray emitting radioactive nuclides from the Fukushima Dai-ichi Nuclear Power Plant accident. J. Environ. Radioact. 2015, 139, 308-319. [CrossRef] [PubMed]

6. Mikami, S.; Maeyama, T.; Hoshide, Y.; Sakamoto, R.; Sato, S.; Okuda, N.; Demongeot, S.; Gurriaram, R.; Uwamino, Y.; Kato, H.; et al. Spatial distributions of radionuclides deposited onto ground soil around the Fukushima Dai-ichi Nuclear Power Plant and their temporal change until December 2012. J. Environ. Radioact. 2015, 139, 320-343. [CrossRef] [PubMed]

7. Ministry of Education, Culture, Sports, Science and Technology (MEXT). Monitoring Information of Environmental Radioactivity Level about Aircraft Monitoring, 2011. Japanese. Available online: http: / / radioactivity.mext.go.jp/ja / (accessed on 5 November 2012).

8. He, Q.; Walling, D.E. Interpreting particle size effects in the adsorption of ${ }^{137} \mathrm{Cs}$ and unsupported ${ }^{210} \mathrm{~Pb}$ by mineral soils and sediments. J. Environ. Radioact. 1996, 30, 117-137. [CrossRef]

9. Tsukada, H.; Takeda, A.; Hisamatsu, S.; Inada, J. Concentration and specific activity of fallout ${ }^{137}$ Cs in extracted and particle-size fractions of cultivated soils. J. Environ. Radioact. 2008, 99, 875-881. [CrossRef] [PubMed]

10. Evrard, O.; Laceby, J.P.; Lepage, H.; Onda, Y.; Cerdan, O.; Ayrault, S. Radiocesium transfer from hillslopes to the Pacific Ocean after the Fukushima Nuclear Power Plant accident: A review. J. Environ. Radioact. 2015, 148, 92-110. [CrossRef] [PubMed]

11. Ueda, S.; Hasegawa, H.; Kakiuchi, H.; Akata, N.; Ohtsuka, Y.; Hisamatsu, S. Fluvial discharge of radiocaesium from watersheds contaminated by the Fukushima Dai-ichi Nuclear Power Plant accident, Japan. J. Environ. Radioact. 2013, 118, 96-104. [CrossRef] [PubMed]

12. Yoshimura, K.; Onda, Y.; Sakaguchi, A.; Yamamoto, M.; Matsuura, Y. An extensive study of the concentrations of particulate/dissolved radiocaesium derived from the Fukushima Dai-ichi Nuclear Power Plant accident in various river systems and their relationship with catchment inventory. J. Environ. Radioact. 2015, 139, 370-378. [CrossRef] [PubMed]

13. Sakaguchi, A.; Tanaka, K.; Iwatani, H.; Chiga, H.; Fan, O.; Onda, Y.; Takahahi, Y. Size distribution studies of ${ }^{137} \mathrm{Cs}$ in river water in the Abukuma Riverine system following the Fukushima Dai-ichi Nuclear Power Plant accident. J. Environ. Radioact. 2015, 139, 379-387. [CrossRef] [PubMed]

14. Tanaka, K.; Iwatani, H.; Sakaguchi, A.; Fan, Q.; Takahashi, Y. Size-dependent distribution of radiocesium in riverbed sediments and its relevance to the migration of radiocesium in river system after the Fukushima Daiichi Nuclear Power Plant accident. J. Environ. Radioact. 2015, 139, 390-397. [CrossRef] [PubMed]

15. Iwasaki, T.; Nabi, M.; Shimizu, Y.; Kimura, I. Computational modeling of ${ }^{137}$ Cs contamination transfer associated with sediment transport in Abukuma River. J. Environ. Radioact. 2015, 139, 416-426. [CrossRef] [PubMed]

16. Saegusa, H.; Ohyama, T.; Iijima, K.; Onoe, H.; Takeuchi, R. Deposition of radiocesium on the river flood plains around Fukushima. J. Environ. Radioact. 2016, 164, 36-46. [CrossRef] [PubMed]

17. Iwagami, S.; Tsujimura, M.; Onda, Y.; Nishino, M.; Konuma, R.; Abe, Y.; Hada, M.; Pun, I.; Sakaguchi, A.; Kondo, H.; et al. Temporal changes in dissolved ${ }^{137} \mathrm{C}$ s concentrations in groundwater and stream water in Fukushima after the Fukushima Dai-ichi Nuclear Power Plant accident. J. Environ. Radioact. 2017, 166, 458-465. [CrossRef] [PubMed] 
18. Kurikami, H.; Kitamura, A.; Yokuda, S.T.; Onishi, Y. Sediment and ${ }^{137}$ Cs behaviors in the Ogaki Dam Reservoir during a heavy rainfall event. J. Environ. Radioact. 2014, 137, 10-17. [CrossRef] [PubMed]

19. Eyrolle-Boyer, F.; Boyer, P.; Garcia-Sanchez, L.; Metivier, J.M.; Onda, Y.; Vismes, A.D.; Cagnat, X.; Boulet, B.; Cossonnet, C. Behaviour of radiocaesium in coastal rivers of the Fukushima Prefecture (Japan) during conditions of low flow and low turbidity-Insight on the possible role of small particles and detrital organic compounds. J. Environ. Radioact. 2016, 151, 328-340. [CrossRef] [PubMed]

20. Vakulovsky, S.M.; Nikitin, A.I.; Chumichev, V.B.; Katrich, I.Y.; Voitsekhovich, O.A.; Medinets, V.I.; Pisarev, V.V.; Bovkum, L.A.; Khersonsky, E.S. Cesuim-137 and Strontium-90 contamination of water bodies in the areas affected by releases from the Chernobyl nuclear power plant accident: An overview. J. Environ. Radioact. 1994, 23, 103-122. [CrossRef]

21. International Atomic Energy Agency (IAEA). Environmental Consequences of the Chernobyl Accident and Their Remediation: Twenty Years of Experience; IAEA: Vienna, Austria, 2006.

22. International Atomic Energy Agency (IAEA). Radiological Conditions in the Dnieper River Basen: Assessment by an International Expert Team and Recommendations for an Action Plan; IAEA: Vienna, Austria, 2006.

23. Saxén, R.; Ilus, E. Discharge of ${ }^{137} \mathrm{Cs}$ and ${ }^{90} \mathrm{Sr}$ by Finnish rivers to the Baltic Sea in 1986-1996. J. Environ. Radioact. 2001, 54, 275-291. [CrossRef]

24. Spezzano, P.; Bortoluzzi, S.; Giacomelli, R.; Massironi, L. Seasonal variations of ${ }^{137}$ Cs activities in the Dola Baltea River (northwest Italy) after the Chernobyl accident. J. Environ. Radioact. 1994, 22, 77-88. [CrossRef]

25. Shizuma, K.; Fujikawa, Y.; Kurihara, M.; Sakurai, Y. Identification and temporal decrease of ${ }^{137} \mathrm{Cs}$ and ${ }^{134} \mathrm{Cs}$ in groundwater in Minami-Soma City following the accident at the Fukushima Dai-ichi nuclear power plant. Environ. Pollut. 2017, 234, 1-8. [CrossRef] [PubMed]

26. Nagao, S.; Kanamori, M.; Ochiai, S.; Tomihara, S.; Fukushi, K.; Yamamoto, M. Export of ${ }^{134}$ Cs and ${ }^{137}$ Cs in the Fukushima river systems at heavy rains by Typhoon Roke in September 2011. Biogeoscience 2013, 10, 6215-6223. [CrossRef]

27. Ministry of Education, Culture, Sports, Science and Technology in Japan. Radioactivity Measurement; Series No. 13; Japan Chemical Analysis Center: Chiba, Japan, 1982. (In Japanese)

28. Hirose, K.; Aoyama, M.; Sugimura, Y. Plutonium and Cesium isotopes in river waters in Japan. J. Radioanal. Nucl. Chem. 1990, 141, 191-202. [CrossRef]

29. Aoyama, M.; Hirose, K.; Miyano, T.; Igarashi, Y. Low-level ${ }^{137}$ Cs measurements in deep seawater samples. Appl. Radiat. Isot. 2000, 53, 159-162. [CrossRef]

30. Sakaguchi, A.; Kadokura, A.; Steier, P.; Tanaka, K.; Takahashi, Y.; Chiga, H.; Matsushima, A.; Nakashima, S.; Onda, Y. Isotopic determination of $\mathrm{U}, \mathrm{Pu}$, and $\mathrm{Cs}$ in environmental waters following the Fukushima Daiichi Nuclear Power Plant accident. Geochem. J. 2012, 46, 355-360. [CrossRef]

31. Godoy, J.M.; Guimaraes, J.R.D.; Carvalho, Z.L. ${ }^{137}$ Cs pre-concentration from water samples using a Prussian blue impregnated ion-exchanger. J. Environ. Radioact. 1993, 20, 213-219. [CrossRef]

32. Shizuma, K.; Takatori, H.; Takenaka, K.; Murataka, A.; Kojima, Y.; Endo, S. Measurement of uranium, radium and radon concentration in groundwater sampled over Hiroshima Prefecture, Japan. Radioisotopes 2010, 59, 163-171. [CrossRef]

33. Shizuma, K.; Fukami, K.; Iwatani, K.; Hasai, H. Low-background shielding of Ge detectors for the measurement of residual ${ }^{152} \mathrm{Eu}$ radioactivity induced by neutrons from the Hiroshima atomic bomb. Nucl. Instrum. Methods Phys. Res. 1992, B66, 459-464. [CrossRef]

34. Shizuma, K.; Oba, Y.; Takada, M. A practical method for determining $\gamma$-ray full-energy peak efficiency considering coincidence-summing and self-absorption corrections for the measurement of environmental samples after the Fukushima reactor accident. Nucl. Instrum. Methods Phys. Res. 2016, 383, 183-190. [CrossRef]

(C) 2018 by the authors. Licensee MDPI, Basel, Switzerland. This article is an open access article distributed under the terms and conditions of the Creative Commons Attribution (CC BY) license (http:// creativecommons.org/licenses/by/4.0/). 